\title{
THE EFFECT OF DICALCIUM SILICATE ON AN ACID SOIL ${ }^{1}$
}

\author{
BURT L. HARTWELL AND F. R. PEMBER \\ Rhode Island Agricultural Experiment Station
}

Received for publication May 27, 1920

At the meeting of the American Chemical Society at Boston in 1917 Cowles (1) and Scheidt presented experimental data with plants from which they concluded that dicalcium silicate has a greater value than either ground limestone or calcium hydrate as a fertilizer material, and that silicon is an essential element and promotes plant growth. ${ }^{2}$

Upon the solicitation of Mr. Cowles, who desired to have the work repeated with other soils and under other conditions, advantage was' taken of an opportunity afforded in connection with an experiment conducted for another purpose, to include "dicalcium silicate" and "hydrated silica," prepared by the Electric Smelting and Aluminum Company, Sewaren, N. J., of which Mr. Cowles is president.

According to Mr. Cowles, 75 to 80 per cent of the dicalcium silicate may be considered as having the composition of $(\mathrm{CaO})_{2} \mathrm{SiO}_{2}$, the remainder being zeolitic material composed of sodium, calcium, aluminum and silicon which has resisted the solvent action of boiling water for an hour. The following analyses accompanied the material:

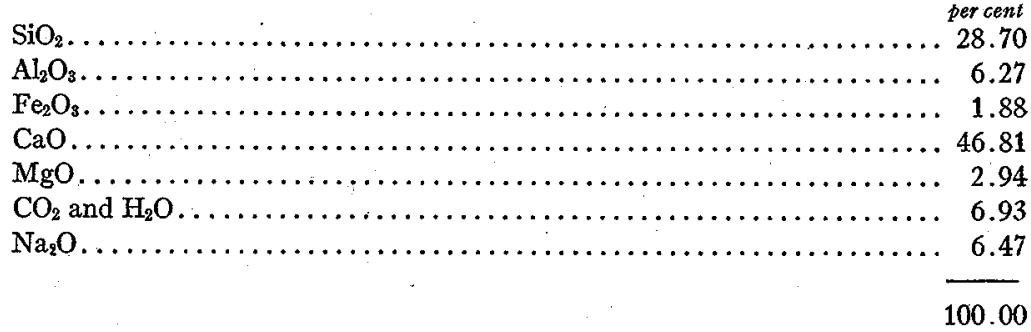

It is the leached residue of a sinter produced from a mixture of silicates, lime and sodium carbonate in the manufacture of disodium aluminate.

The hydrated silica was reported as having the following composition:

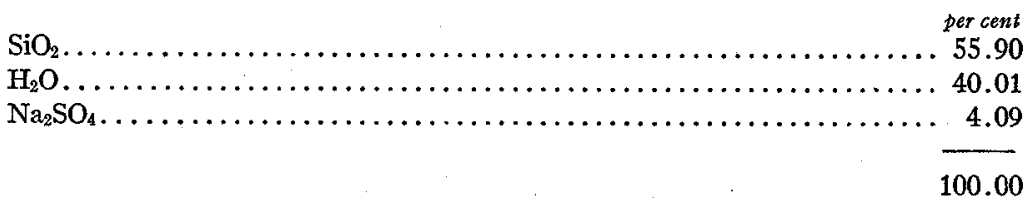

${ }^{1}$ Contribution 271 from the Rhode Island Agricultural Experiment Station at Kingston.

${ }^{2}$ Results published by the Electric Smelting and Aluminum Company, Sewaren, N. J. 
The Miami silt loam which was used in the pot experiment involving these materials was taken near the Rhode Island Agricultural Experiment Station plats and had been in turf for many years without manurial treatment. Fifteen pounds of the soil containing 18 per cent moisture were used in each 8-inch Wagner pot.

The alkaline materials and the largest applications of acid phosphate were added on May 6, 1919, so that they could react with the soil prior to the addition to each pot, on May 24, of the following basal fertilizer:

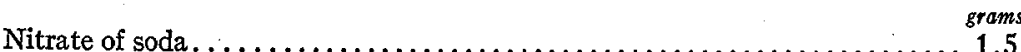

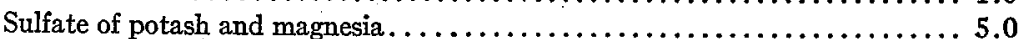

Acid phosphate............................................... 3.5

On July 5, $1 \mathrm{gm}$. each of nitrate of soda and sulfate of potash was also added.

Cos lettuce was planted on May 26, but in some cases more seed had to be added on June 6 . On July 3, final thinning was made to 6 plants per pot. Where plants of the first seeding had to be supplemented by those of the second seeding a somewhat uneven growth resulted, and the parallelism from duplicate pots was less satisfactory than it would have been had there been always the same proportions of plants from the first and second seeding. It is believed, however, that conclusions are warranted, even though the results are not closely quantitative. The crop was harvested on July 22.

The special applications in addition to the basal fertilizer, and the yields resulting from them, are given in table 1.

It may be seen that where only the basal application of fertilizer was applied without any other additions (pair 1), the lettuce made only a very small growth. Pairs 9, 10 and 11 show that maximum growth was attained by different proportions of calcium carbonate and acid phosphate, and even by a very large application of acid phosphate (pair 13). If desired to estimate the applications on an acre basis, it may be observed that $7.25 \mathrm{gm}$. per pot is equivalent to 1 ton per acre. It was shown by other pots that the basal fertilizer supplied enough for nutrient purposes.

Concerning an investigation described by the authors in another paper (2) the following statement was made at the close: "The results indicate that the practical advantage of phosphating and liming may often prove to be due to the precipitation of active aluminum quite as much as to supplying phosphorus as a nutrient, and lime as a reducer of acidity."

By comparing pairs 2 and 3 it appears that the dicalcium silicate corrected the condition about equally with an equivalent amount of limestone. Full opportunity was given for each to exert its maximum effect, as shown by the fact that in pair 4, 50 per cent additional limestone increased the growth.

There were no indications that the silicon in the dicalcium silicate was of any value. The same is true of the silicon in the hydrated silica, as may be seen by comparing pair 5 without-and pair 6 with-hydrated silica; or again, 
pair 7 without-and pair 8 with-hydrated silica. The smaller yield in one of pair 7 seems to be attributable to the fact that five of the six plants were the partially developed ones of the second planting previously referred to.

The dicalcium silicate was as effective as limestone in counteracting the toxic conditions existing in the acid soil, but there was no evidence that there is any justification in claiming an additional value because of its content of silicon.

- TABLE 1

Yields of dry cos lettuce leaves from duplicate pots, with the extra applications in addition to the basal fertilizer

\begin{tabular}{|c|c|c|}
\hline PAIR & EXTRA APPLICATIONS & $\begin{array}{l}\text { YIELDS OP } \\
\text { DRYLETYUCE } \\
\text { LEAVES }\end{array}$ \\
\hline & & gm. \\
\hline 1 & 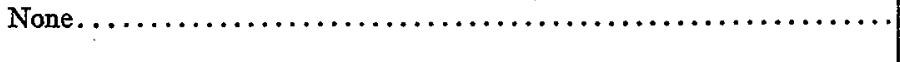 & $\begin{array}{l}3.0 \\
4.5\end{array}$ \\
\hline 2 & 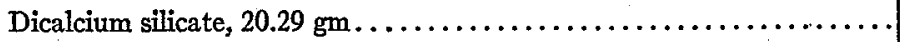 & 12.0 \\
\hline & & 13.0 \\
\hline 3 & 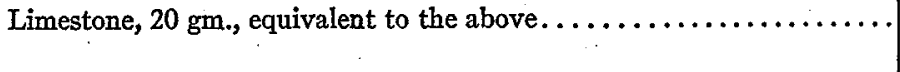 & $\begin{array}{l}11.5 \\
12.0\end{array}$ \\
\hline 4 & 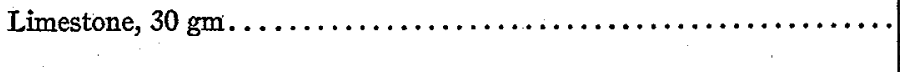 & $\begin{array}{l}15.0 \\
18.5\end{array}$ \\
\hline 5 & 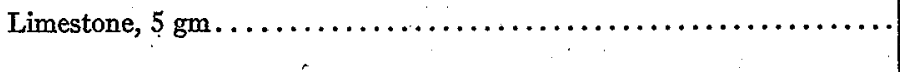 & $\begin{array}{r}9.0 \\
11.0\end{array}$ \\
\hline 6 & Limestone, 5 gm.; hydrated silica, 7.25 gm. (1 ton per acre). . . . . . & $\begin{array}{r}7.0 \\
10.0\end{array}$ \\
\hline 7 & Limestone, $5 \mathrm{gm}$; acid phosphate, $16: 5 \mathrm{gm} . \ldots \ldots \ldots \ldots \ldots \ldots \ldots \ldots$ & $\begin{array}{r}9.0 \\
18.0\end{array}$ \\
\hline 8 & Limestone, 5 gm.; acid phosphate, $16.5 \mathrm{gm}$; hydrated silica, $7.25 \mathrm{gm} . .$. & $\begin{array}{l}19.5 \\
20.0\end{array}$ \\
\hline 9 & Limestone, $5 \mathrm{gm}$; acid phosphate, $26.5 \mathrm{gm} . \ldots \ldots \ldots \ldots \ldots \ldots \ldots \ldots$ & $\begin{array}{l}20.0 \\
21.0\end{array}$ \\
\hline 10 & Limestone, $10 \mathrm{gm} . ;$ acid phosphate, $11.5 \mathrm{gm} . \ldots \ldots \ldots \ldots \ldots \ldots \ldots$ & $\begin{array}{l}19.0 \\
19.0\end{array}$ \\
\hline 11 & 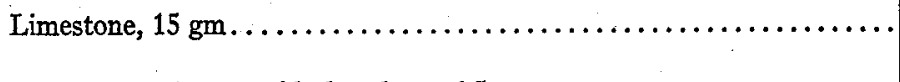 & $\begin{array}{r}8.5 \\
10.0\end{array}$ \\
\hline 12 & Limestone, 15 gm.; acid phosphate, $6.5 \mathrm{gm} \ldots \ldots \ldots \ldots \ldots \ldots \ldots \ldots$ & $\begin{array}{l}17.0 \\
19.0\end{array}$ \\
\hline 13 & Acid phosphate, 100 gm. $\ldots \ldots \ldots \ldots \ldots \ldots \ldots \ldots \ldots \ldots \ldots \ldots \ldots$ & $\begin{array}{l}21.0 \\
23.0\end{array}$ \\
\hline
\end{tabular}

Even if it should ever be proved that, contrary to the opinion now generally held, silicon is an essential element, it seems probable that there would be enough of it active in our siliceous soils to satisfy all needs.

It should occasion no surprise if silicon were to have an advantageous indirect effect under conditions which were not shown to be optimum. If such an effect were observed, however, it would, obviously, be no proof that silicon is essential to plant growth. : 


\section{REFERENCES}

(1) Cowles, Alfred H. 1917 Calcium silicates as fertilizers. In Metal. Chem. Engin., v. 17, p. 664-665.

(2) Hartwell, Burt L., and Pember, F. R. 1918 The presence of aluminum as a reason for the difference in the effect of so-called acid soil on barley and rye. In Soil Sci., v. 6, p. 259-277. 